\title{
Is the occurrence of a sigmoidal ventral border in Cyprideis torosa (Jones) valves linked to salinity? A morphometrical analysis approach
}

\author{
F. Grossi ${ }^{*}$, S. Da Prato² \& E. Gliozzi ${ }^{1}$ \\ ${ }^{1}$ Dipartimento di Scienze, Università Roma Tre, Largo S. Leonardo Murialdo, 1, I-00146, Roma, Italy \\ ${ }^{2}$ Istituto di Geoscienze e Georisorse - CNR, Via Moruzzi, 1 - 56124 Pisa, Italy \\ *Correspondence: francesco.grossi@uniroma3.it
}

\begin{abstract}
The living euryhaline species Cyprideis torosa (Jones) undergoes morphometric variations in size, noding and sieve-pore shape linked to environmental parameters. In particular it is known that salinity values around $8-9 \%$ represent the osmoregulation threshold and the turning point between smaller and greater valves and prevailingly noded as opposed to un-noded valves. Here, a character never studied before is analysed: the relationship between salinity and the C. torosa valve outlines, especially the morphology of the ventral border. Geometric-morphometric analysis was carried out on different populations of $C$. torosa collected in oligohaline (Massaciuccoli marsh, Tuscany, and Lake Trasimeno, Umbria) and hyperhaline waterbodies (Trapani-Paceco salt pans, Sicily). The results indicate that the species displays two morphotypes: a dominant one, characterized by a straight ventral border; and a morphotype with a sigmoidal profile ventral border. This latter morphotype seems to be related to higher salinity: the oligohaline waters are characterized only by $C$. torosa individuals with straight ventral outline, while the hyperhaline environments are marked by the occurrence of $17.6 \%$ of sigmoidal individuals. Furthermore, the sigmoidal ventral border is more emphasized in males than in females.
\end{abstract}

Keywords: Ostracoda, Cyprideis, geometric-morphometric analysis, ecophenotypic morphotypes, oligohaline environments, hyperhaline environments, Italy

Received 13 May 2016; accepted 6 June 2016

Among benthic invertebrates, ostracods are particularly sensitive to environmental changes, being strongly dependent on several physico-chemical parameters: temperature, waterbody turbidity, energy level, chemistry of the water, dissolved oxygen content, food supply and nature of the substrate (Rodriguez-Lazaro \& Ruiz-Muñoz 2012). Thus, they represent valuable proxies for environmental and palaeoenvironmental reconstructions.

The euryhaline species Cyprideis torosa (Jones) can withstand and thrive in a very wide range of salinity (from 0.4 to $150 \%$ according to Neale (1988) and Griffiths \& Holmes (2000)), but its carapace records salinity variations through changes in some morphological traits. This species is thus commonly regarded as a valuable palaeosalinometer for the Quaternary marginal-marine and athalassic brackish deposits (Pint et al. (2012) with references therein). Many ecophenotypic studies have been carried out on C. torosa. Since the pioneering studies by Schäfer (1953), Sandberg (1964), Vesper (1975) and Rosenfeld \& Vesper (1977), it is known that this species undergoes morphological variations in size, ornamentation, noding and sieve-pore shape linked to physical and chemical environmental parameters (especially salinity), testifying to a clear environmentally cued polymorphism (Carbonel 1982; Aladin 1993; Van Harten 1996, 2000; Keyser \& Aladin 2004; Keyser 2005; Boomer \& Frenzel 2011; Frenzel et al. 2011, 2012; Boomer et al. 2016, among others). Gliozzi et al. 2016 have shown that the valve outline is genotypically fixed, independent from environmental changes. However, in some populations of $C$. torosa a few specimens occur that display an anomalous sigmoidal ventral margin in lateral outline (Fig. 1). The aim of this work is to evaluate the occurrence of this trait through geometric-morphometric analysis and look for possible correlations with the salinity range.

\section{Material and methods}

Living and Recent populations of C. torosa from different environmental conditions were sampled from the Massaciuccoli marsh (Tuscany, Recent), Lake Trasimeno (Umbria, living) and Trapani and Paceco salt pans (Sicily, Recent) (Fig. 2; Table 1).

The Massaciuccoli palustrine marsh is amongst the most important wetlands in Tuscany. It is a coastal lagoon with fresh to oligohaline water located at the foot of the southern Apuan Alps, which drains a total basin area of about $112 \mathrm{~km}^{2}$ and opens to the sea by way of an artificial channel (Baneschi 2007). A sampling campaign of the present palustrine bottom was carried out during June 2015. Cyprideis torosa populations analysed in this work are from 5 samples collected on the NE shore of the lake at depths between 0.9 and $2 \mathrm{~m}$, bottom temperature from 24.5 to $26^{\circ} \mathrm{C}$, bottom $\mathrm{pH} 7.65-8$ and salinity values between 0.6 and $0.77 \%$, in the oligohaline range.

Lake Trasimeno (Umbria) is the largest Italian shallow endorheic lake (average depth around $4.7 \mathrm{~m}$ ) located within the central Apennine chain at an elevation of $252 \mathrm{~m}$ above sea-level. The present lake bottom was sampled during July 2014 along the southern and southeastern shores of the lake and on a north-south transect from Polvese Island to the Anguillara Channel (Marchegiano, M., Gliozzi, E., Ceschin, S., Mazzini, I., Mazza, R. \& Ariztegui, D. submitted. Investigating the living ostracod assemblages of Lake Trasimeno (Umbria, central Italy). Journal of Limnology, Pallanza). Cyprideis torosa specimens were collected from 22 samples at depths between 1.4 and $5.2 \mathrm{~m}$, bottom temperature from 23 to $25.3^{\circ} \mathrm{C}$, bottom $\mathrm{pH} 7.4-8.7$ and salinity values between 0.84 and $0.89 \%$, in the oligohaline range. 


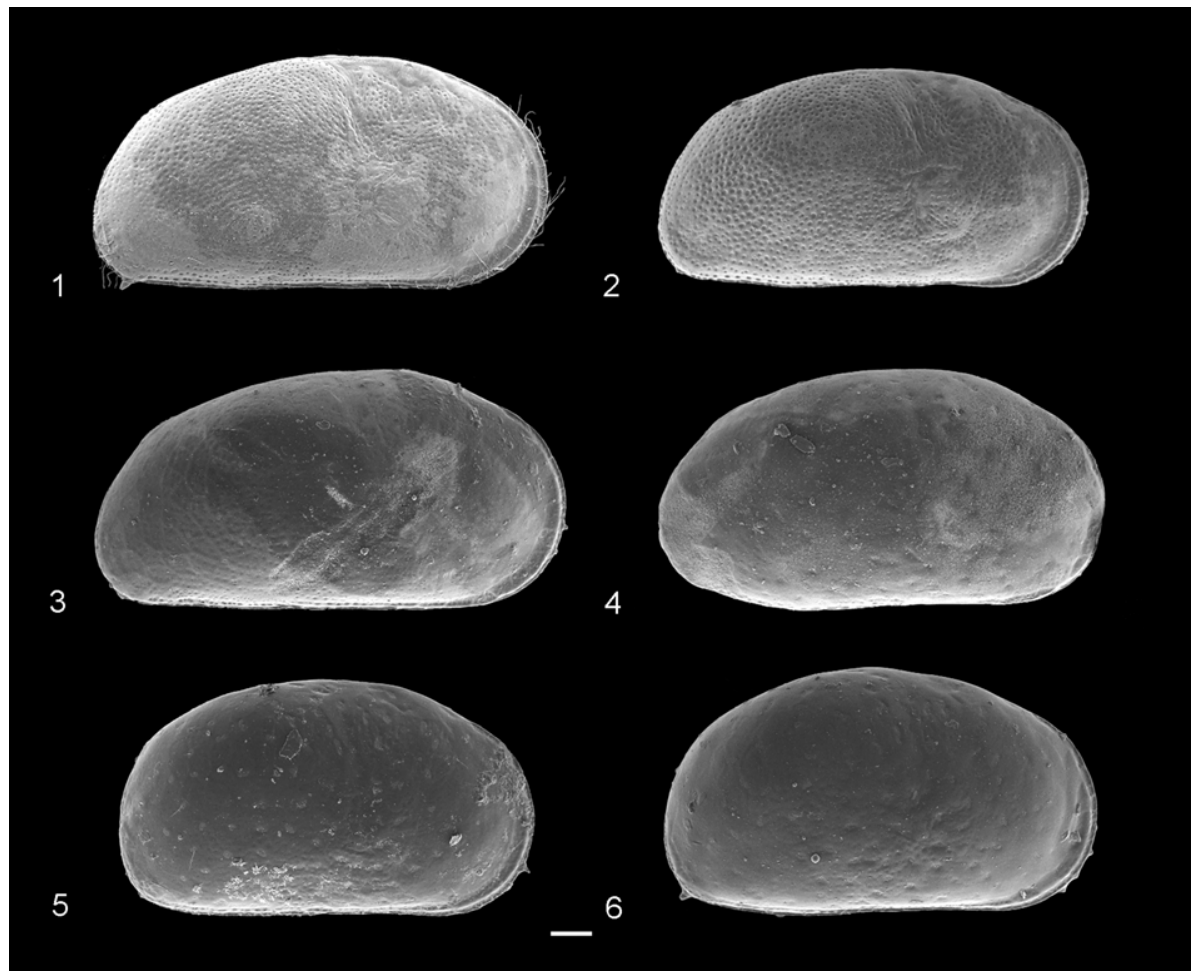

Fig. 1. Scanning electron microscope (SEM) images of Cyprideis torosa right valves with straight and sigmoidal ventral border: $\mathbf{1}$, male valve with straight ventral border, Lake Trasimeno (PAN15); 2, male valve with sigmoidal ventral border, Lake Trasimeno (PAN15); 3, male valve with straight ventral border, Galia salt pan; $\mathbf{4}$, male valve with sigmoidal ventral border, Galia salt pan; 5, female valve with straight ventral border, Galia salt pan; 6 , female valve with sigmoidal ventral border, Bella salt pan. Scale bar $100 \mu \mathrm{m}$.

The Trapani-Paceco salt pans (southwestern Sicily) are one of the most important natural reserves of the region (Maccotta et al. 2013) and, at present, they produce more than three thousand tons of salt per year. Cyprideis torosa specimens were collected during May 2015 from four different salt pans: Salinella, Bella, Maria Stella and Galia. Measured salinities in situ gave hyperhaline values of 60, 99, 119 and $137 \%$, respectively, but since only dead carapaces and

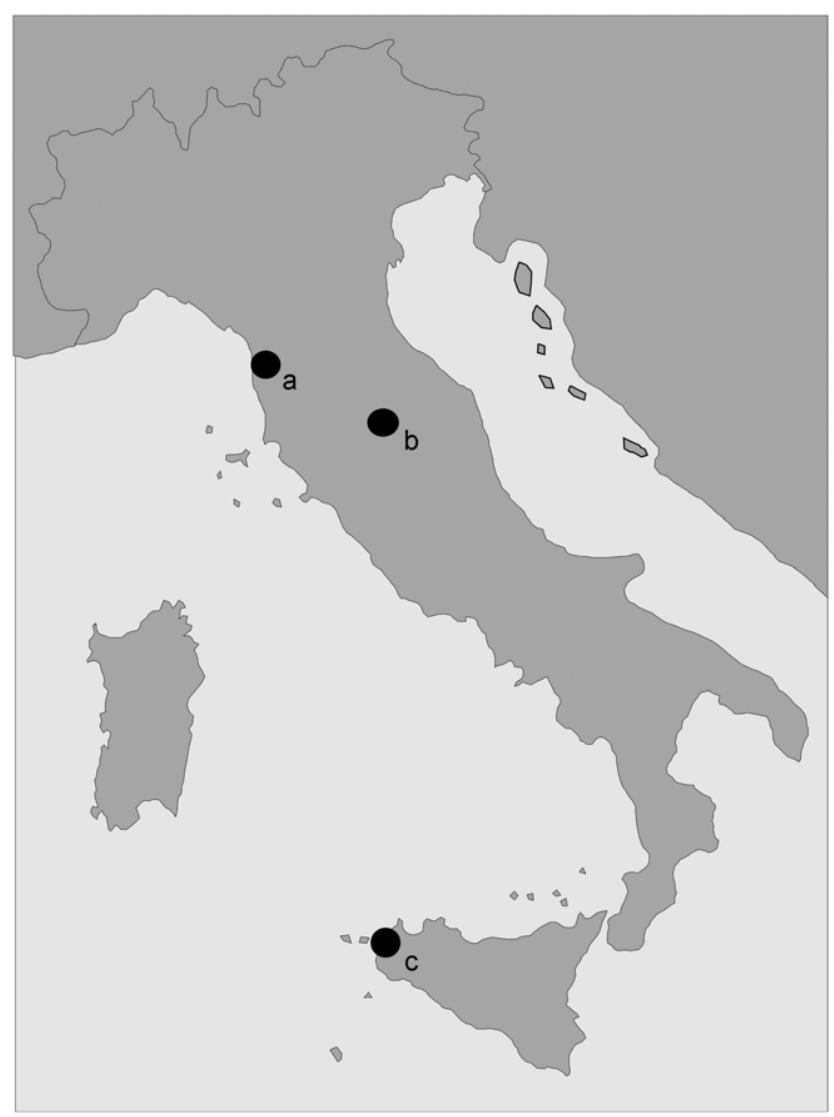

Fig. 2. Geographical map of Italy with the studied locations: (a) Massaciuccoli marsh; (b) Lake Trasimeno; (c) Trapani-Paceco salt pans. loose valves were recovered, the salinities of the different ponds were calculated through the transfer function elaborated by Frenzel et al. (2011) and Pint et al. (2012) on the basis of the percentage of the rounded sieve pores (the correlation coefficient between measured and estimated salinities of this transfer function is $R^{2}=0.95$ ). Consequently, the salinities inferred at the moment when C. torosa was living are as follows: Maria Stella 44\%o, Galia $61 \%$, Salinella $70 \%$ and Bella $80 \%$, still in the hyperhaline range.

Samples from Massaciuccoli, Trasimeno and Trapani-Paceco were preserved in the field in $75 \%$ ethanol, washed in the laboratory with tap water through a $125 \mu \mathrm{m}$ mesh sieve and dried in an oven at $40^{\circ} \mathrm{C}$. Manual picking was carried out under a stereo-microscope on the dried sieved samples to reach up to 300 valves. Using stereomicroscope and scanning electron microscope (SEM) photographs, geometric-morphometric analysis on female and male valves was performed. Photos were processed with the tpsDig software (Rohlf 2009) to digitize the valve outline. Outlines were analysed using Morphomatica (Linhart et al. 2006) and the results were processed through multivariate analyses using different algorithms: Cluster Analysis (UPGMA, Euclidean distance) and ANOSIM Pairwise Tests by means of the Primer software (Clarke \& Gorley 2006).

\section{Geometric-morphometric analysis of the valve outlines}

Geometric-morphometric analysis of Cyprideis torosa valve outline was performed on the male and female, right and left adult valves. Since no differences were detected between right and left valves herein, we present only the results provided by the male and female right valves.

Figures 3-5 illustrate the results of the geometric-morphometric analysis of right male valves from the different analysed localities. Figure 3 shows the superimposition of the outlines in "normalized for area' mode: the specimens from Massaciuccoli (Fig. 3a) do not show any undulation of the ventral margin, which, on the contrary, is just detectable in the Trasimeno specimens (Fig. 3b) and rather more clearly evident in some specimens recovered in the Trapani salt pans (Fig. 3c-f). Figure 4 illustrates the superimposition of the mean outlines of the 'straight' morphotype (blue line) and the 'sigmoidal' one (red line) for each locality in 'normalized for area' mode in the left 

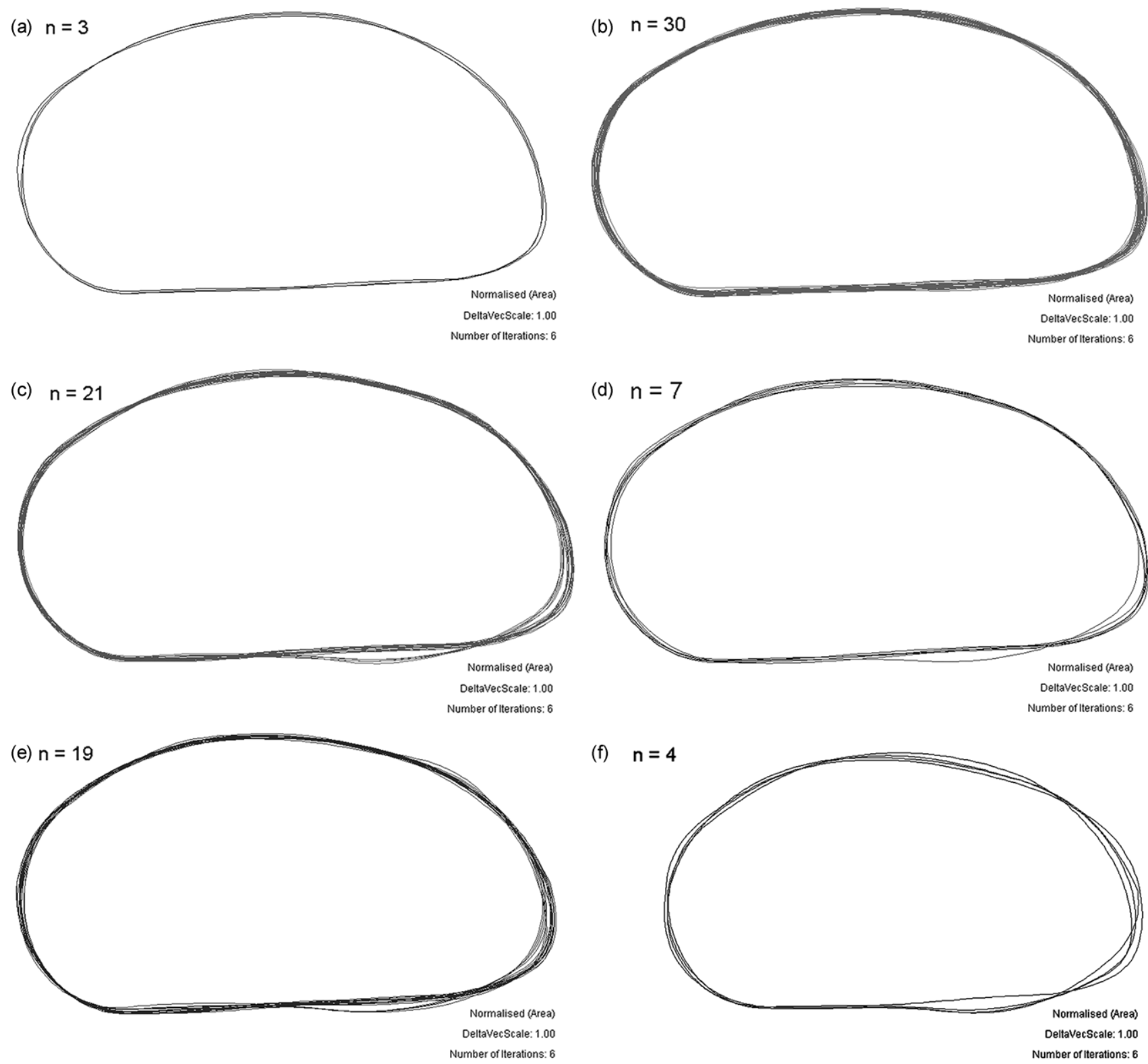

Fig. 3. Results of the geometric-morphometric analysis in 'normalized for area' mode performed on the right male valves of Cyprideis torosa: (a) Massaciuccoli marsh; (b) Lake Trasimeno; (c) Maria Stella salt pan; (d) Galia salt pan; (e) Salinella salt pan; (f) Bella salt pan.

column and 'not normalized for area' mode in the right column. This type of output better illustrates that specimens from Lake Trasimeno (Fig. 4a) do not show a substantial undulation of the ventral margin, while it is evident in the salt pans populations (Fig. 4b-e), especially in the Bella salt pan (Fig. 4e). Cluster Analysis (UPGMA, Euclidean distance) and ANOSIM Pairwise Tests were performed to assess if these male outline differences were statistically significant, and the results are shown in Figure 5. The dendrogram obtained for the Lake Trasimeno outlines (Fig. 5a) shows a mixing of 'straight' and sigmoidal specimens, while those for Maria Stella and Salinella salt pans (Fig. $5 \mathrm{~b}$ and c) show that straight and sigmoidal morphotypes are split into two different clusters, characterized by an intrapopulational dissimilarity close to the value of 40 . The Global $\mathrm{R}$ values calculated by the ANOSIM Pairwise Tests are 0.14 (Lake Trasimeno), 0.99 (Maria Stella salt pan) and 0.90 (Salinella salt pan), respectively. This last result confirms that $C$. torosa male valves collected in Lake Trasimeno are not characterized by a statistically significant dissimilarity, whilst in the Maria Stella and Salinella salt pans the morphotypes are very different.
Figures 6-7 show the same analyses performed on the right female valves. Massaciuccoli and Trasimeno female valves (Fig. 6a and b) do not show any ventral undulation, whilst some females collected from the Salinella and Bella salt pans display a sigmoidal ventral margin (Fig. 6e-f) very similar to those of the males, although the undulation is less accentuated and the sigmoidal morphotype is present with very low percentages (see Table 2). Mean female outlines of the last two localities are shown in Figure 7, where it is evident that the differences between the two morphotypes are less accentuated than in the male valves. This is further confirmed by the multivariate analysis that shows no cluster subdivisions (Fig. 8) and Global $\mathrm{R}$ values calculated by the ANOSIM Pairwise Tests of 0.478 .

\section{Discussion}

The results of the geometric-morphometric analyses carried out on different populations of Cyprideis torosa collected in oligohaline and hyperhaline waterbodies indicate that the species displays two 
(a) $\begin{array}{r}n=12 \\ n=15\end{array}$
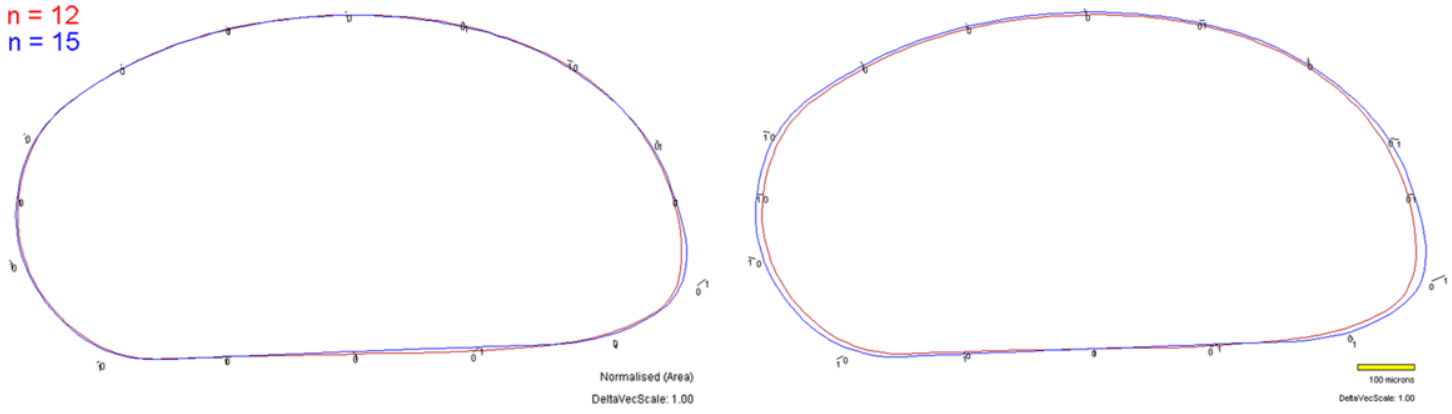

$n=6$

(b)
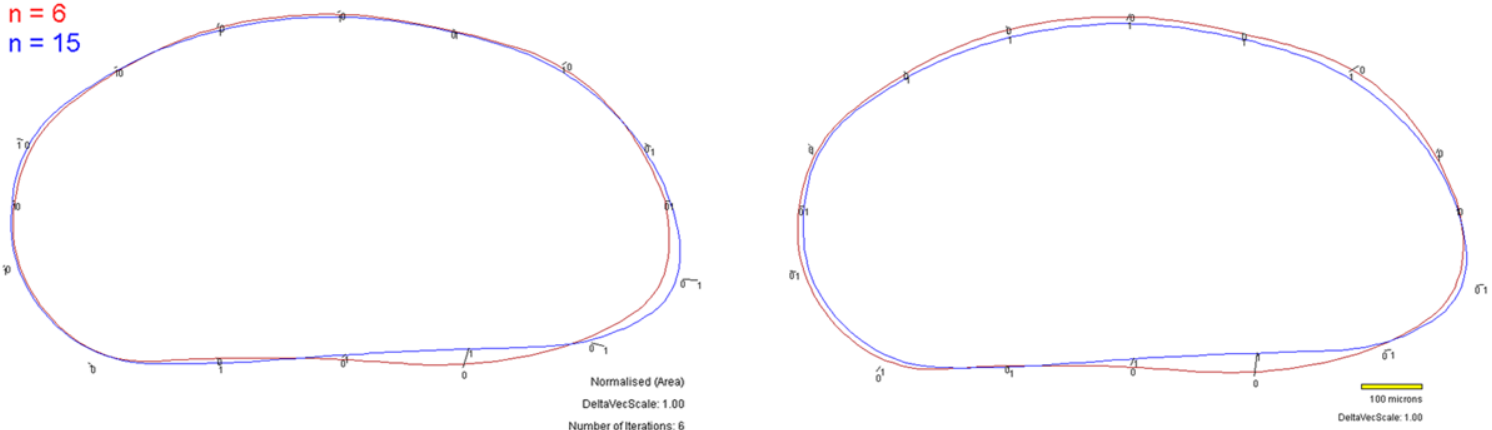

(c) $\begin{aligned} & n=1 \\ & n=6\end{aligned}$
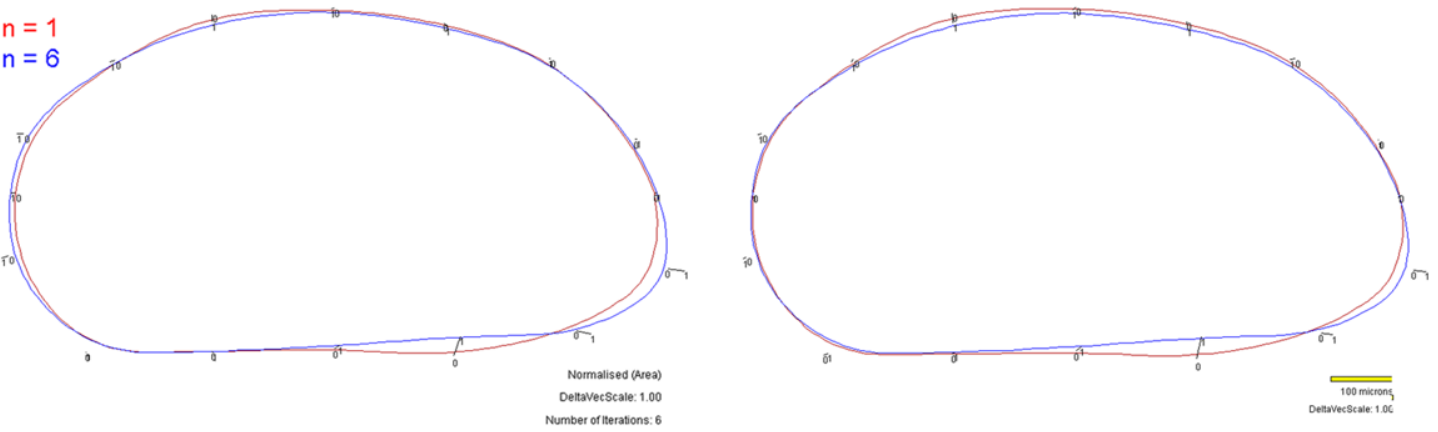

(d) $\begin{aligned} & n=4 \\ & n=15\end{aligned}$
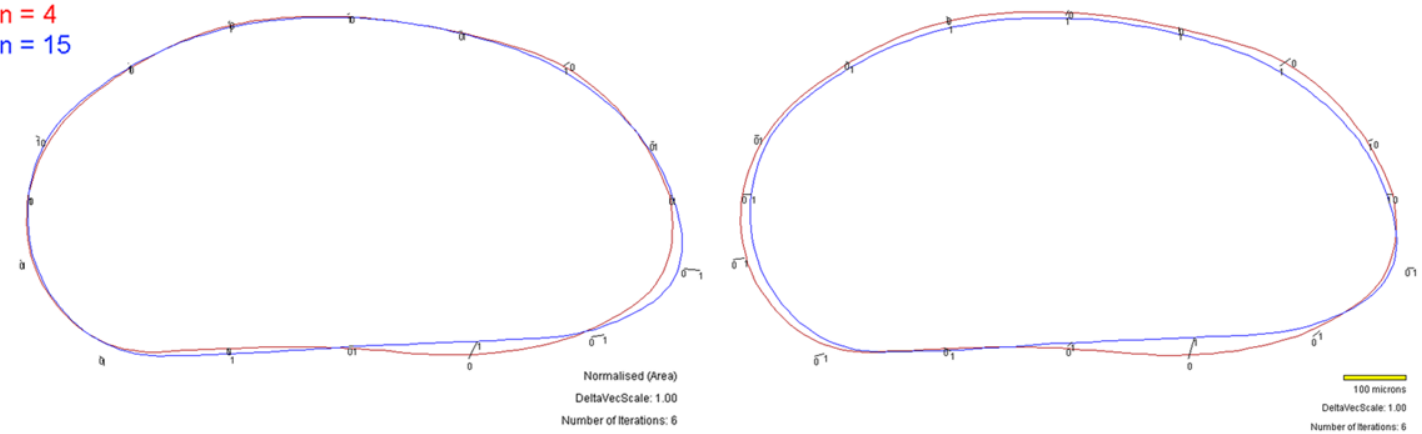

$n=3$
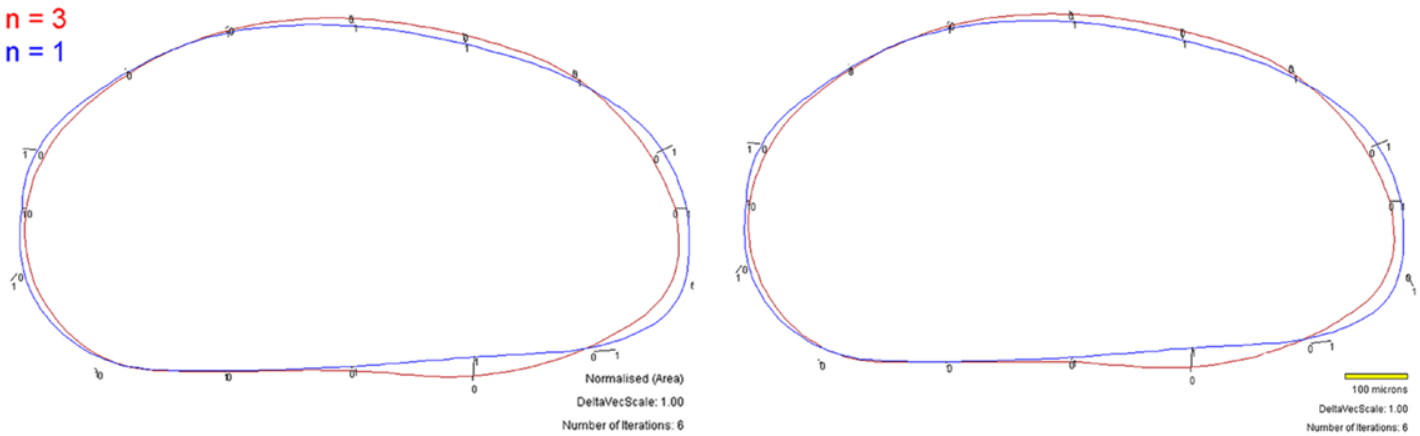

Fig. 4. Results of the geometric-morphometric analysis in 'normalized for area' mode (left column) and 'not normalized for area' mode (right column) performed on the right male mean outlines of Cyprideis torosa with straight ventral border (1, blue line) and sigmoidal ventral border ( 0 , red line): (a) Lake Trasimeno; (b) Maria Stella salt pan; (c) Galia salt pan; (d) Salinella salt pan; (e) Bella salt pan. 
(a) Lake Trasimeno - right male valves in "normalized for area" mode

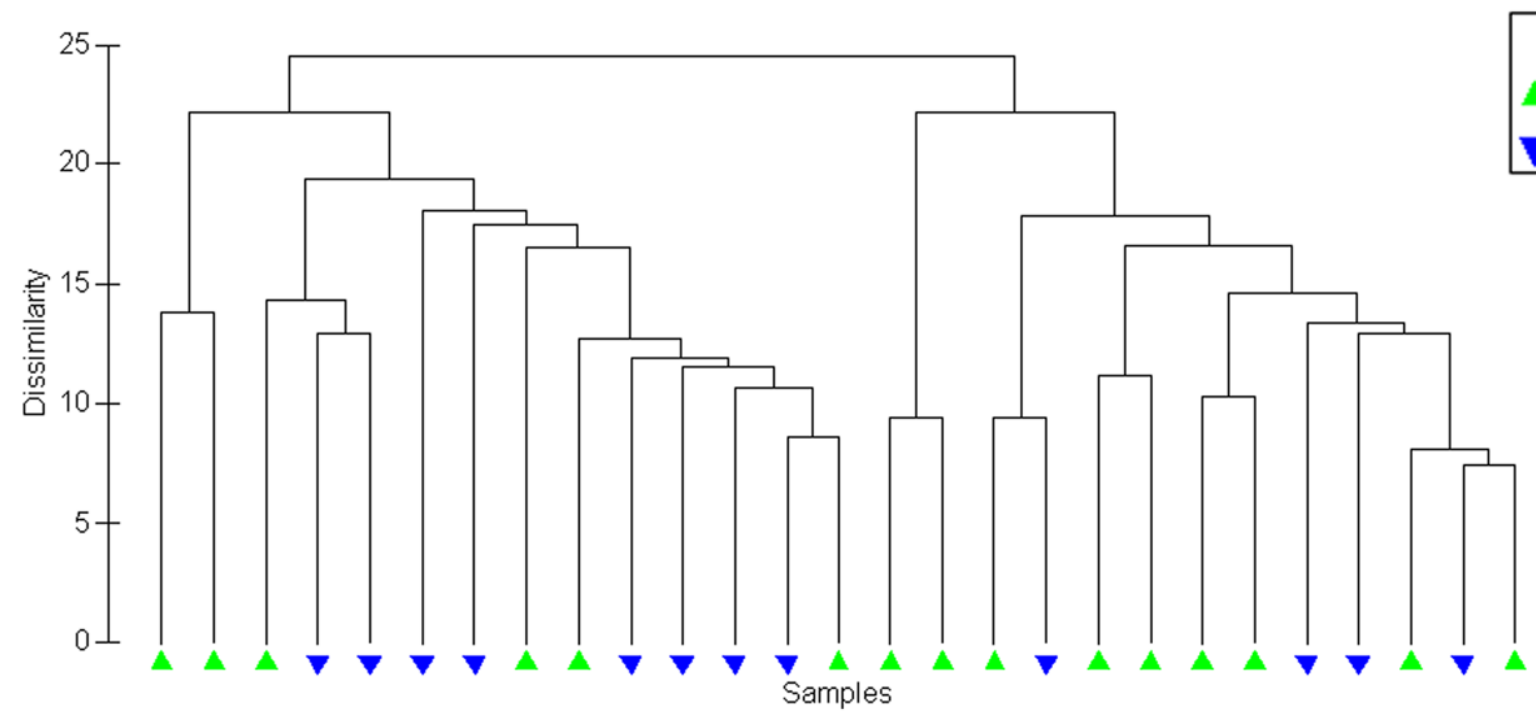

(b) Maria Stella salt pan - right male valves in "normalized for area" mode

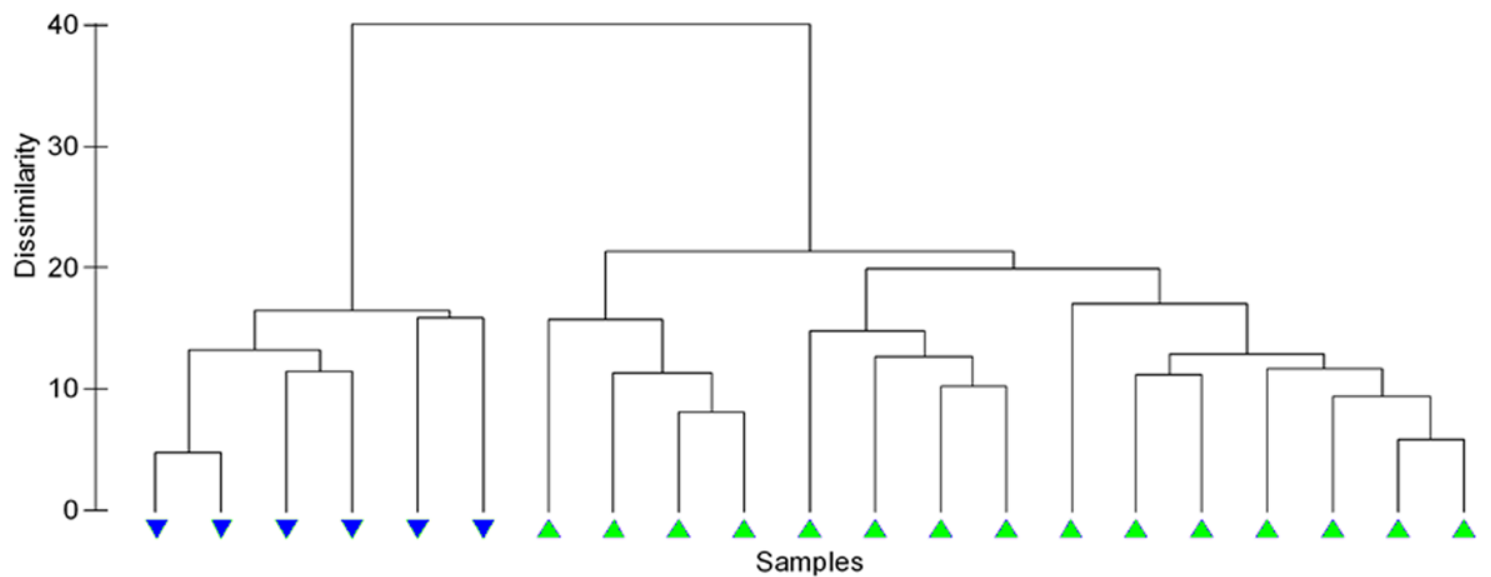

(c) Salinella salt pan - right male valves in "normalized for area" mode

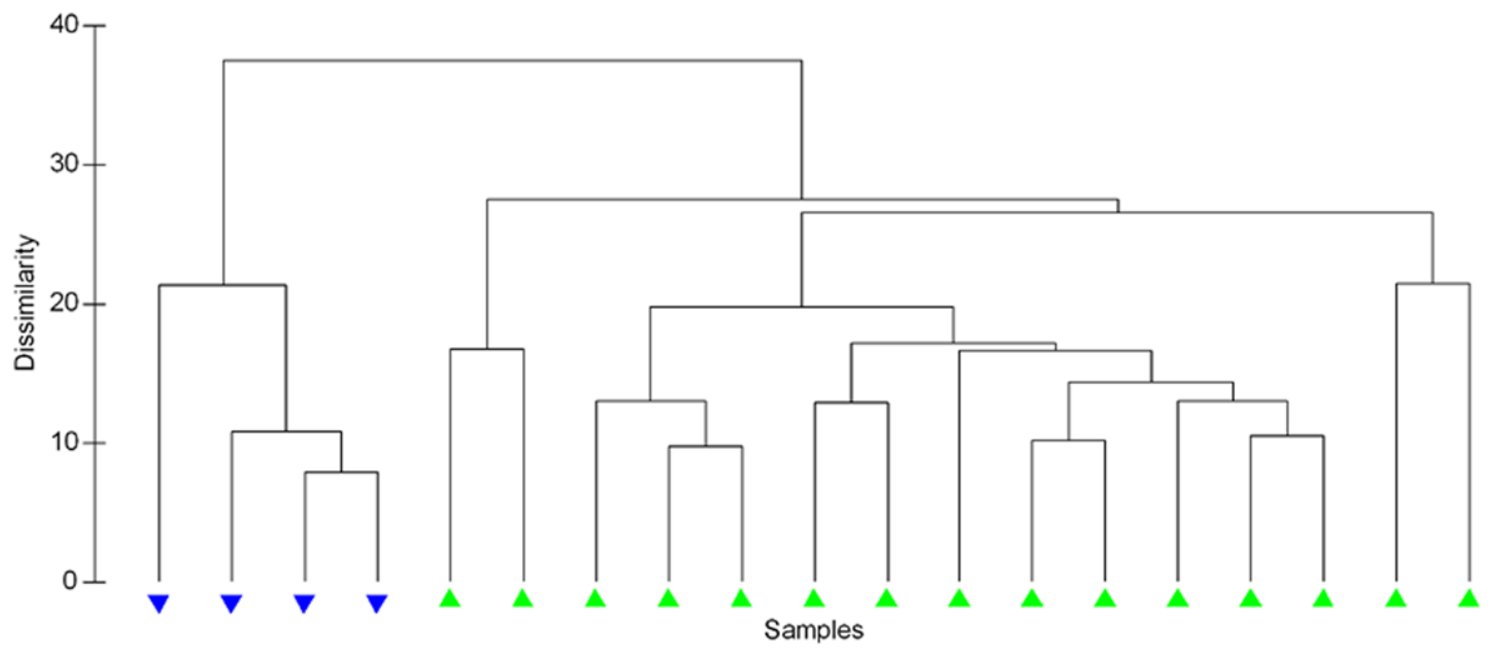

Fig. 5. Results of the Cluster Analysis (UPGMA, Euclidean distance) performed on the right male valves of Cyprideis torosa with straight ventral border and sigmoidal ventral border: (a) Lake Trasimeno; (b) Maria Stella salt pan; (c) Salinella salt pan. 
(a)

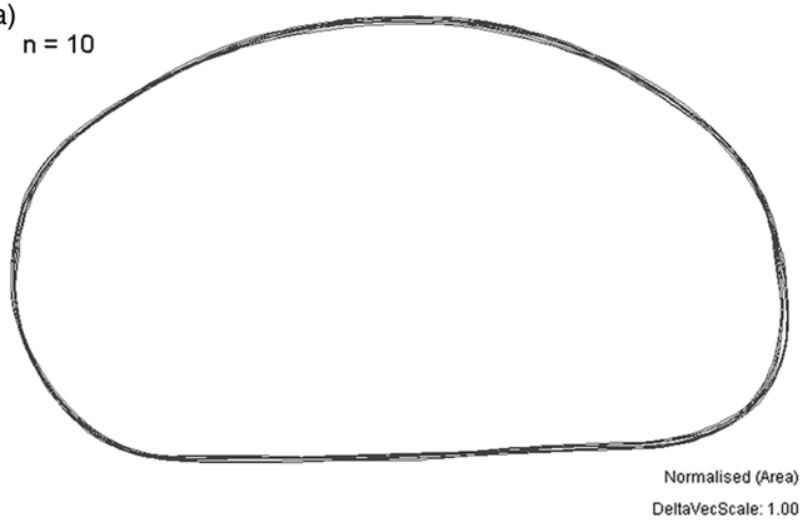

(c)

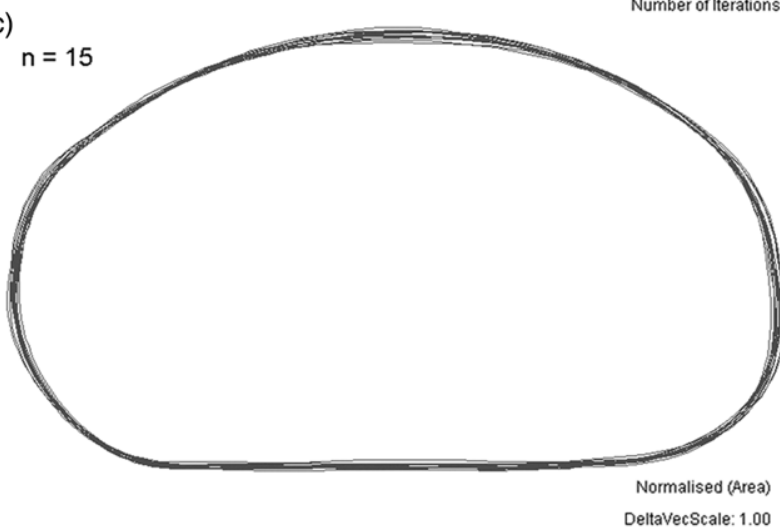

(e) $\mathrm{n}=19$

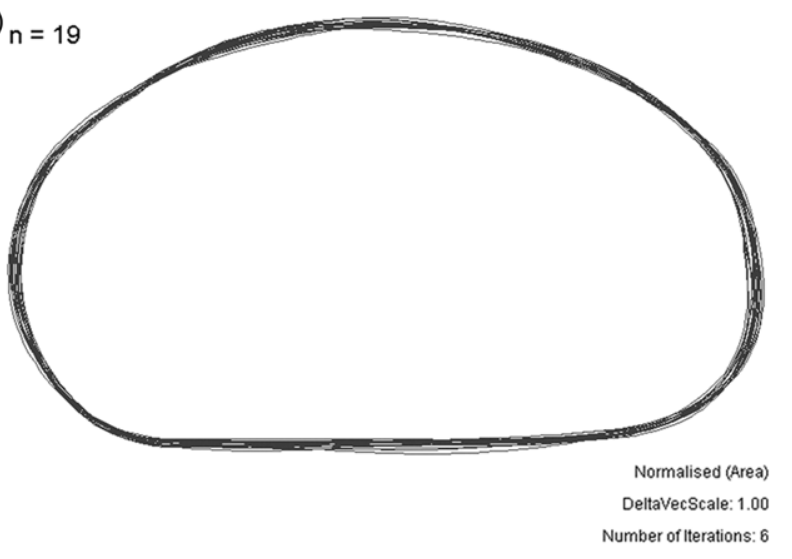

(b)

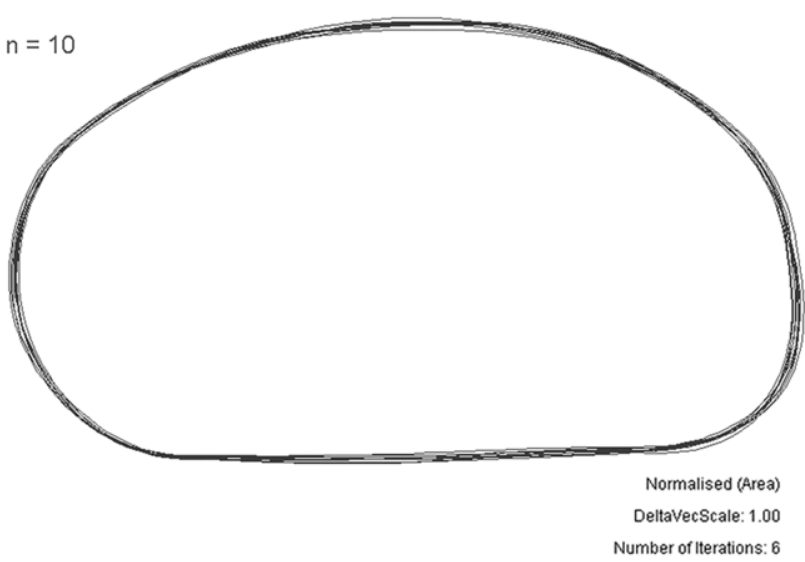

(d)

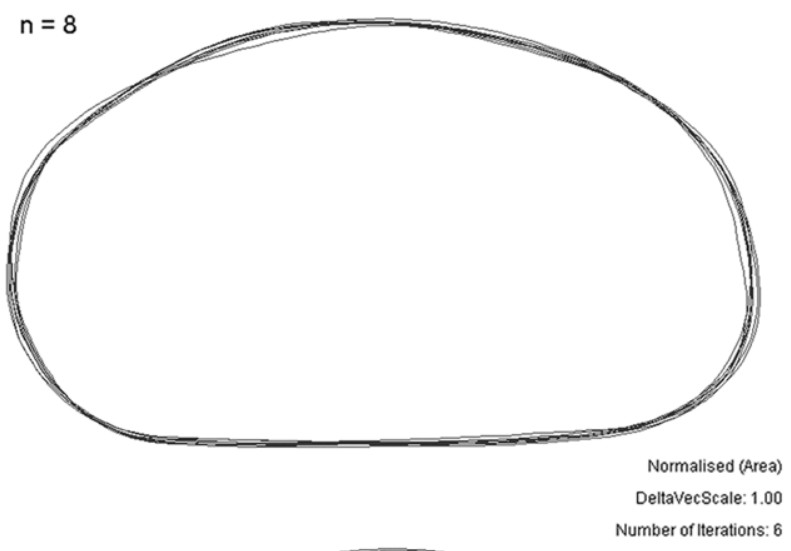

(f)

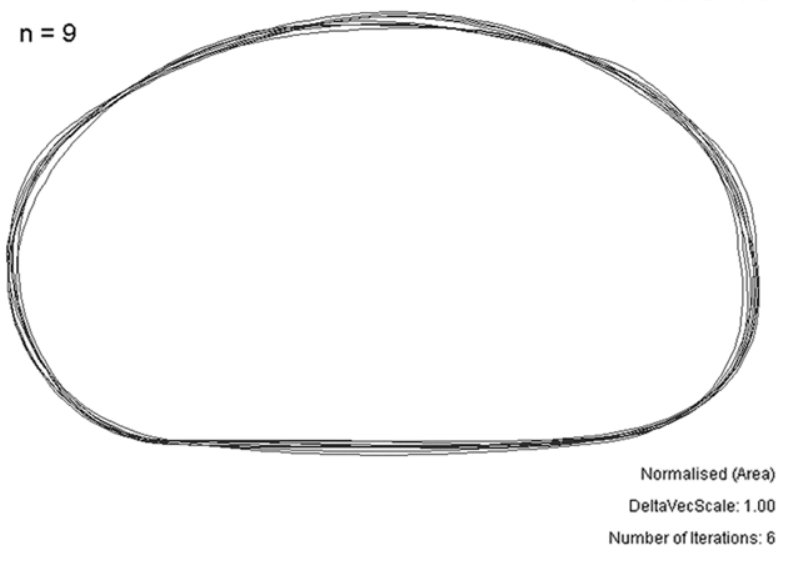

Fig. 6. Results of the geometric-morphometric analysis in 'normalized for area' mode performed on the right female valves of Cyprideis torosa: (a) Massaciuccoli marsh; (b) Lake Trasimeno; (c) Maria Stella salt pan; (d) Galia salt pan; (e) Salinella salt pan; (f) Bella salt pan.

morphotypes: a dominant one characterized by a straight ventral border, and a subordinate morphotype with a sigmoidal ventral profile in lateral view. Table 2 and Figure 9 show the percentage occurrence of the two morphotypes that appears to be strictly related to salinity: the Massaciuccoli and Trasimeno oligohaline waters host only $C$. torosa with a straight outline, while the hyperhaline salt pans are characterized by the occurrence of $17.6 \%$ of sigmoidal male and female individuals. While males show a variable percentage of the sigmoidal morphotype in all the sampled salt pan populations, females display undulated ventral borders only in the more hyperhaline salt pans (Salinella and Bella). Furthermore, male results are more affected by this feature than female, up to $27.5 \%$ (Table 2), and the sigmoidal profile of the ventral border is even more emphasized.

A similar sigmoidal trait has been observed also in other species of Cyprideis. For example, in some specimens of Cyprideis agrigentina Decima collected in the Messinian succession of Eraclea Minoa (Grossi et al. 2015) straight and undulated ventral outlines are observable both in male and in female valves (Fig. 10:5,10:6). On the basis of a molecular biogeochemical study, Mezger (2012) suggests, for Eraclea Minoa waterbodies, hyperhaline salinities around 55-80\%. Other species such as Cyprideis rooki Ligios \& Gliozzi, Cyprideis arvedoi Ligios \& Gliozzi and Cyprideis toscana Ligios \& Gliozzi from the middle Tortonian-early Messinian of the Baccinello Basin (Tuscany, central Italy) (Fig. 10:1-4) and Cyprideis ventroundulata Krstić (not figured) normally display a male sigmoidal morphotype, particularly emphasized in the right valve (Krstic 1968; Ligios \& Gliozzi 2012). In those cases no information concerning possible hyperhaline environments has been recovered (Ligios et al. 2008).

The present study reveals that the sigmoidal ventral border can be a distinctive morphological trait for some species, but also one possible morphotype that co-occurs with the more frequent 'normal' straight morphotype in others, suggesting, in this latter case, a possible relationship between the morphology of the ventral border and salinity. Perhaps this feature was not observed before in 

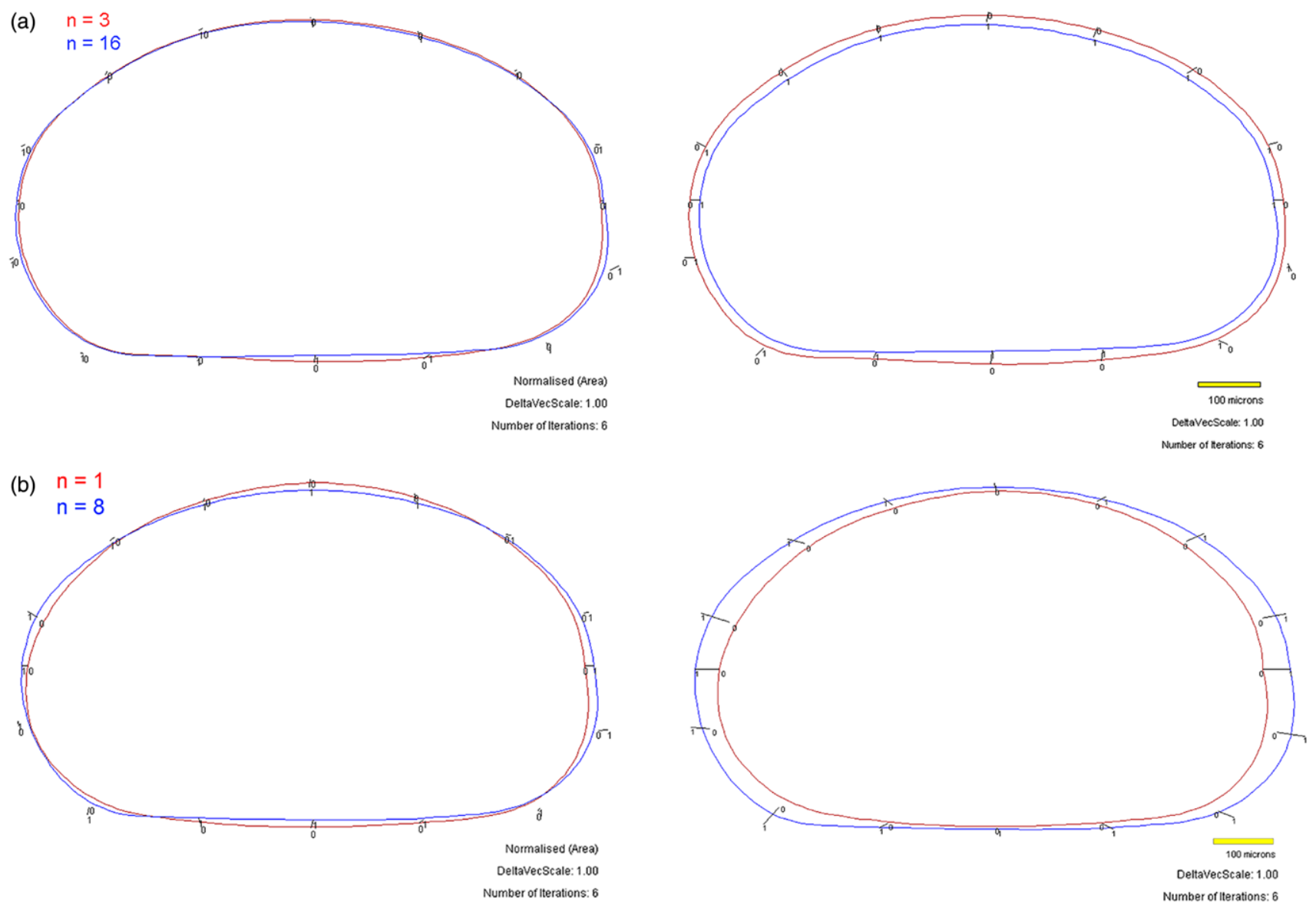

Fig. 7. Results of the geometric-morphometric analysis in 'normalized for area' mode (left column) and 'not normalized for area' mode (right column) performed on the right female mean outlines of Cyprideis torosa with straight ventral border (1, blue line) and sigmoidal ventral border ( 0 , red line): (a) Salinella salt pan; (b) Bella salt pan.

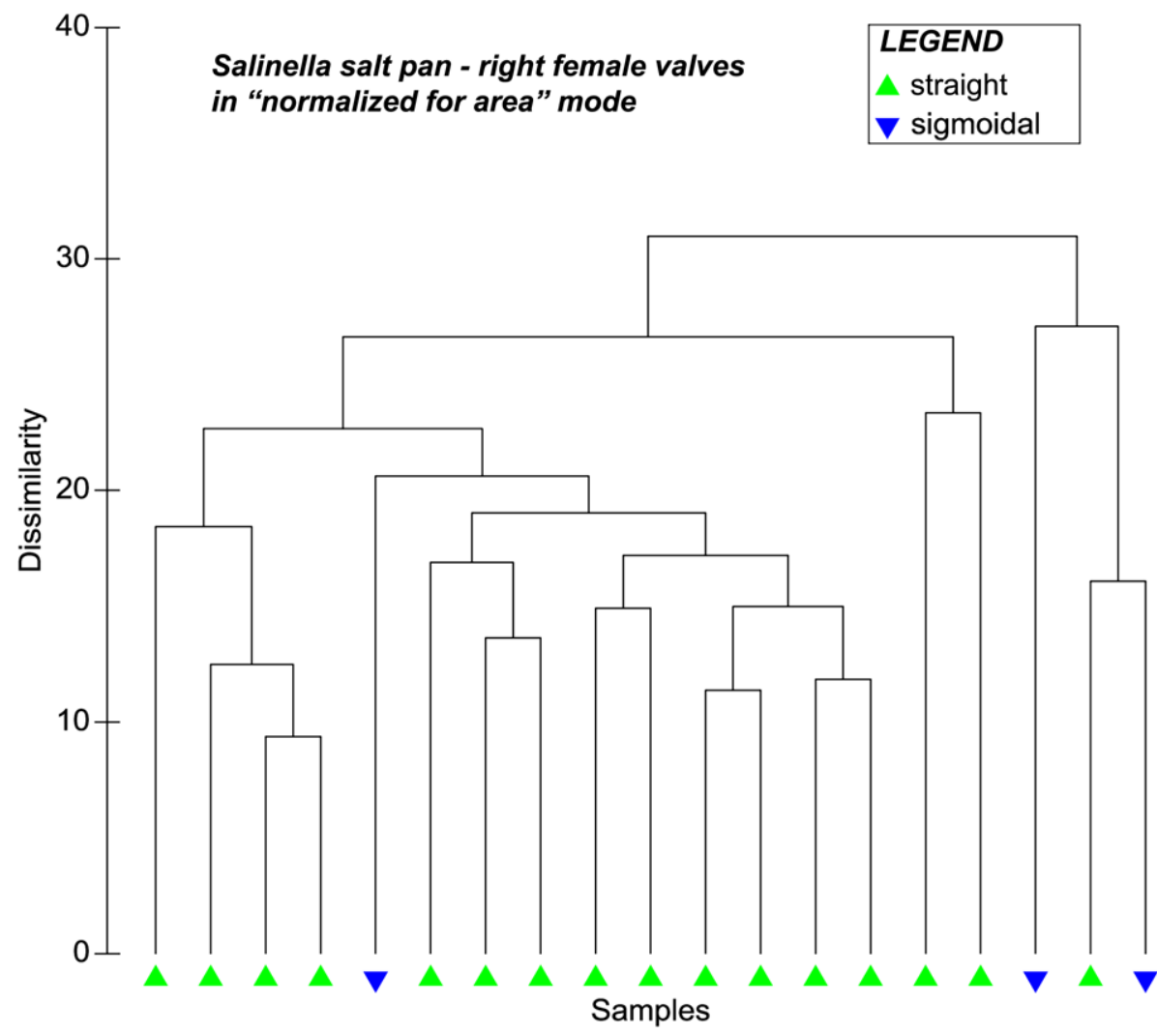

Fig. 8. Results of the Cluster Analysis (UPGMA, Euclidean distance) performed on the right female valves of Cyprideis torosa with straight ventral border and sigmoidal ventral border in the Salinella salt pan. 

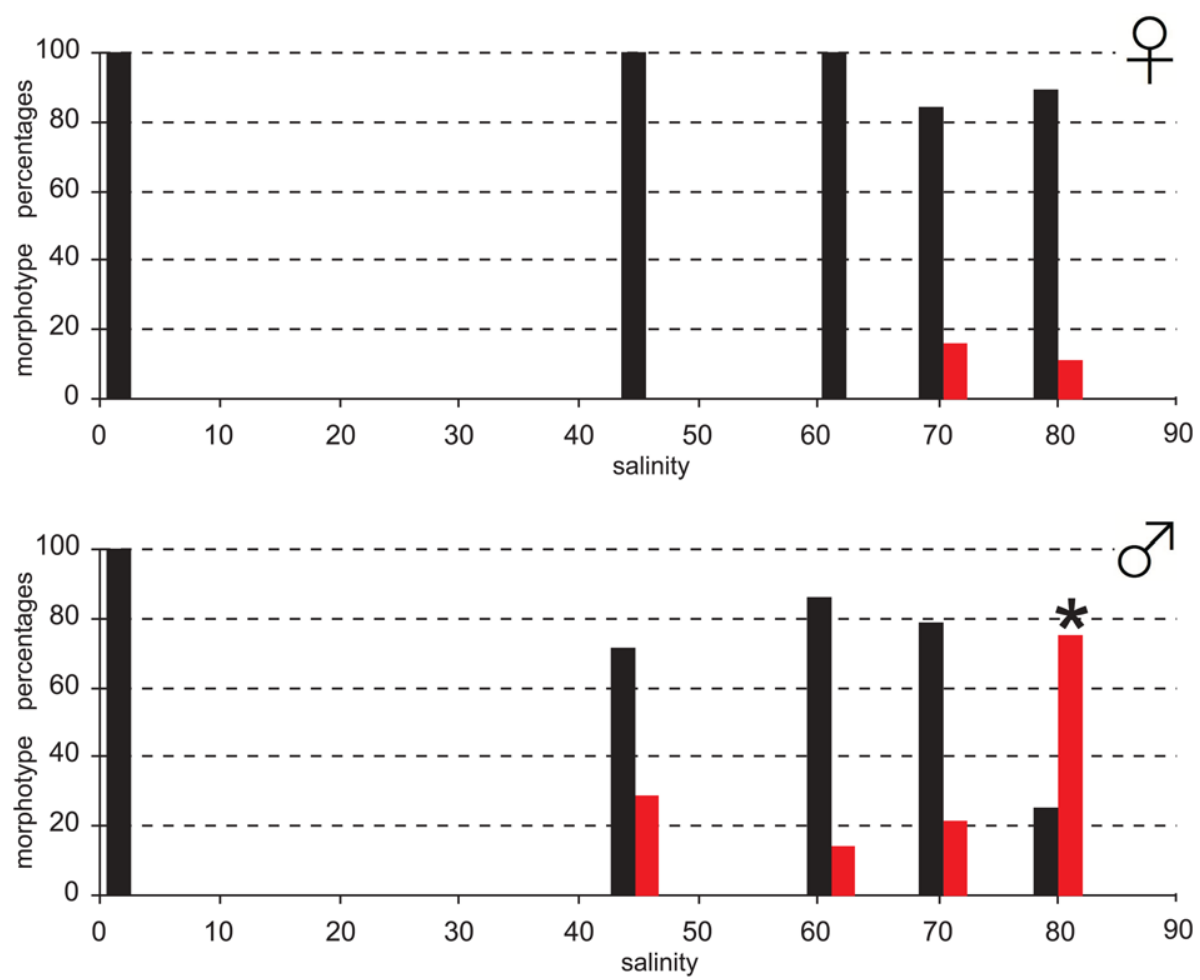

Fig. 9. Percentages of straight and sigmoidal ventral borders in male (below) and female valves (above) of C. torosa plotted against salinity. The asterisk marks the Bella salt pan for which there are few

- straight घ sigmoidal data points.
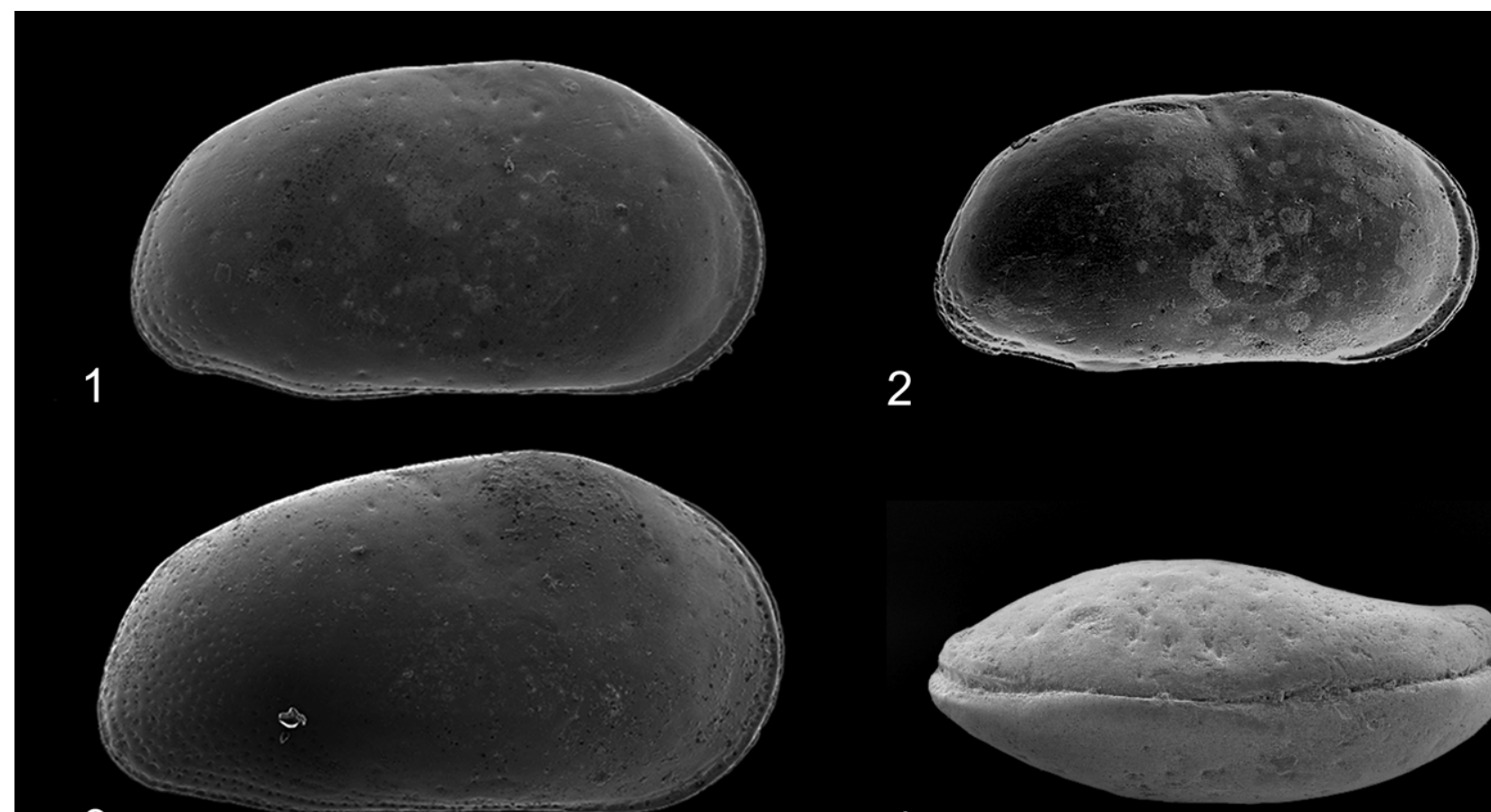

3

4

5

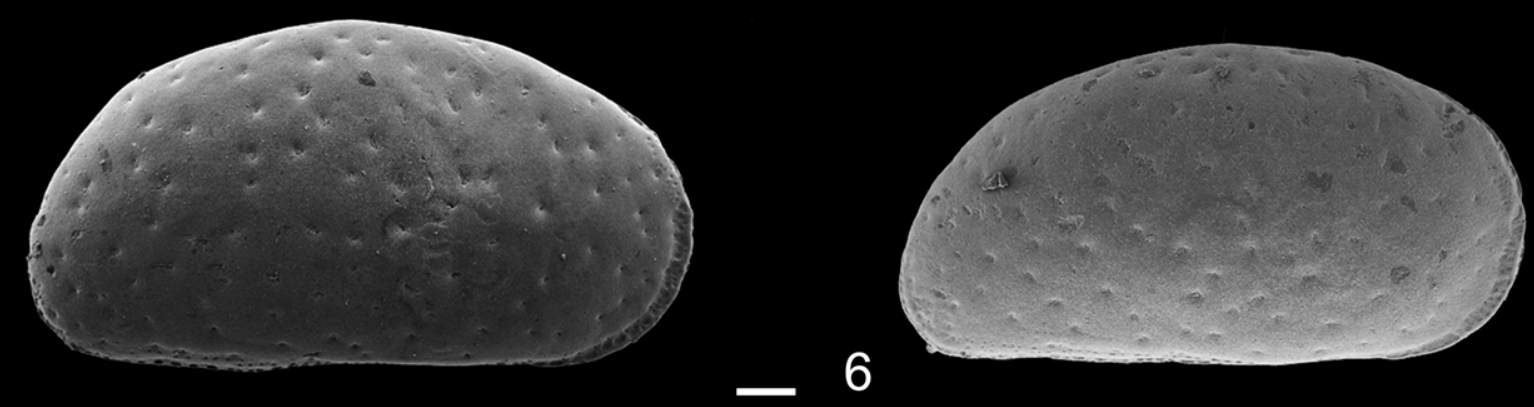

Fig. 10. SEM images of some Cyprideis spp. right male valves: 1, Cyprideis arvedoi, Baccinello Basin (BA38); 2, Cyprides toscana, Baccinello Basin (BA48); 3, Cyprideis rooki, Baccinello Basin (BA40); 4, Cyprideis rooki, specimen with postero-ventral atrophy in dorsal view, Baccinello Basin (BA83); 5, Cyprides agrigentina, sigmoidal morphotype, Eraclea Minoa (EM6"-5); 6, Cyprideis agrigentina, straight morphotype, Eraclea Minoa (EM8-5). Scale bar $100 \mu \mathrm{m}$. 
Table 1. Studied samples and geographical coordinates for each locality

\begin{tabular}{|c|c|c|c|}
\hline Locality & Sample & Latitude & Longitude \\
\hline \multirow{5}{*}{ Massaciuccoli marsh } & LM 2 & $43^{\circ} 50^{\prime} 14.16^{\prime \prime}$ & $10^{\circ} 20^{\prime} 53.1^{\prime \prime}$ \\
\hline & LM 3 & $43^{\circ} 50^{\prime} 43.16^{\prime \prime}$ & $10^{\circ} 20^{\prime} 17.32^{\prime \prime}$ \\
\hline & LM 5 & $43^{\circ} 50^{\prime} 25.62^{\prime \prime}$ & $10^{\circ} 20^{\prime} 20.6^{\prime \prime \prime}$ \\
\hline & LM 7 & $43^{\circ} 50^{\prime} 27.24^{\prime \prime}$ & $10^{\circ} 20^{\prime} 22.14^{\prime \prime}$ \\
\hline & LM 10 & $43^{\circ} 50^{\prime} 22.38^{\prime \prime}$ & $10^{\circ} 20^{\prime} 43.5^{\prime \prime}$ \\
\hline \multirow[t]{22}{*}{ Lake Trasimeno } & PAN 2 & $43^{\circ} 05^{\prime} 19.6^{\prime \prime}$ & $12^{\circ} 08^{\prime} 53.3^{\prime \prime}$ \\
\hline & PAN 3 & $43^{\circ} 05^{\prime} 15.4^{\prime \prime}$ & $12^{\circ} 08^{\prime} 31.8^{\prime \prime}$ \\
\hline & PAN 5 & $43^{\circ} 05^{\prime} 12.2^{\prime \prime}$ & $12^{\circ} 08^{\prime} 16.2^{\prime \prime}$ \\
\hline & PAN 6 & $43^{\circ} 05^{\prime} 04.8^{\prime \prime}$ & $12^{\circ} 08^{\prime} 00.1^{\prime \prime}$ \\
\hline & PAN 7 & $43^{\circ} 04^{\prime} 54.5$ & $12^{\circ} 07^{\prime} 27.2^{\prime \prime}$ \\
\hline & PAN 8 & $43^{\circ} 04^{\prime} 53.7^{\prime \prime}$ & $12^{\circ} 07^{\prime} 02.6^{\prime \prime}$ \\
\hline & PAN 9 & $43^{\circ} 05^{\prime} 03.0^{\prime \prime}$ & $12^{\circ} 06^{\prime} 32.0^{\prime \prime}$ \\
\hline & PAN 10 & $43^{\circ} 05^{\prime} 11.8^{\prime \prime}$ & $12^{\circ} 05^{\prime} 58.5^{\prime \prime}$ \\
\hline & PAN 11 & $43^{\circ} 05^{\prime} 20.1^{\prime \prime}$ & $12^{\circ} 05^{\prime} 46.6^{\prime \prime}$ \\
\hline & PAN 12 & $43^{\circ} 05^{\prime} 20.1^{\prime \prime}$ & $12^{\circ} 05^{\prime} 46.6^{\prime \prime}$ \\
\hline & PAN 15 & $43^{\circ} 05^{\prime} 35.0^{\prime \prime}$ & $12^{\circ} 05^{\prime} 6.5^{\prime \prime}$ \\
\hline & PAN 18 & $40^{\circ} 05^{\prime} 10.9^{\prime \prime}$ & $12^{\circ} 05^{\prime} 48.0^{\prime \prime}$ \\
\hline & PAN 24 & $43^{\circ} 06^{\prime} 18.4^{\prime \prime}$ & $12^{\circ} 11^{\prime} 02.9^{\prime \prime}$ \\
\hline & PAN 29 & $43^{\circ} 07^{\prime} 37.2^{\prime \prime}$ & $12^{\circ} 05^{\prime} 46.8^{\prime \prime}$ \\
\hline & PAN 30 & $43^{\circ} 07^{\prime} 29.9^{\prime \prime}$ & $12^{\circ} 05^{\prime} 41.0^{\prime \prime}$ \\
\hline & PAN 31 & $43^{\circ} 08^{\prime} 00.0^{\prime \prime}$ & $12^{\circ} 05^{\prime} 31.4^{\prime \prime}$ \\
\hline & PAN 32 & $43^{\circ} 08^{\prime} 43.1^{\prime \prime}$ & $12^{\circ} 06^{\prime} 24.0^{\prime \prime}$ \\
\hline & PAN 35 & $43^{\circ} 06^{\prime} 38.3^{\prime \prime}$ & $12^{\circ} 06^{\prime} 37.2^{\prime \prime}$ \\
\hline & PAN 36 & $43^{\circ} 06^{\prime} 16.7^{\prime \prime}$ & $12^{\circ} 06^{\prime} 20.4^{\prime \prime}$ \\
\hline & PAN 37 & $43^{\circ} 05^{\prime} 58.3^{\prime \prime}$ & $12^{\circ} 6^{\prime} 00.3^{\prime \prime}$ \\
\hline & PAN 38 & $43^{\circ} 05^{\prime} 45.2^{\prime \prime}$ & $12^{\circ} 05^{\prime} 33.0^{\prime \prime}$ \\
\hline & PAN 39 & $43^{\circ} 05^{\prime} 27.4^{\prime \prime}$ & $12^{\circ} 05^{\prime} 56.0^{\prime \prime}$ \\
\hline \multirow{4}{*}{$\begin{array}{l}\text { Trapani-Paceco } \\
\text { salt pans }\end{array}$} & GALIA & $37^{\circ} 59^{\prime} 36^{\prime \prime}$ & $12^{\circ} 32^{\prime} 0.5^{\prime \prime}$ \\
\hline & BELLA & $37^{\circ} 59^{\prime} 59^{\prime \prime}$ & $12^{\circ} 32^{\prime} 0.5^{\prime \prime}$ \\
\hline & MARIA STELLA & $37^{\circ} 59^{\prime} 28^{\prime \prime}$ & $12^{\circ} 32^{\prime} 6^{\prime \prime}$ \\
\hline & SALINELLA & $37^{\circ} 58^{\prime} 2^{\prime \prime}$ & $12^{\circ} 30^{\prime} 29^{\prime \prime}$ \\
\hline
\end{tabular}

C. torosa because it is particularly remarkable only in hyperhaline environments, while in oligo- and mesohaline waterbodies it is absent or just detectable. At present we are not able to give further explanation as to why the shells of $C$. torosa (and C. agrigentina) undergo such a modification. The sigmoidal shape somewhat enlarges the postero-ventral area: could this fact be explained as another morphological modification of the valves linked to the osmoregulation processes or could it reflect modifications of the genital apparatus? And, in this latter case, why should it be modified in hyperhaline environments? Could the ventral undulation also be a reaction to parasites? Some cases of parasites that affect the reproductive organs have been hypothesized in the Cyprideis species occurring in the middle Tortonian levels of the Baccinello sedimentary succession (Ligios \& Gliozzi 2012). Here, Cyprideis valves are affected also by an abnormal lateral depression of the postero-marginal area in the female and male right valves (Fig. 10). This morphological feature was described by Ruggieri (1962, p. 24) for some specimens referred to Hermanites, Carinocythereis and Occultocythereis as 'right postero-ventral atrophy' that could most probably be linked to a sort of unilateral parasitical castration, induced by dinoflagellates, bacteria or trematodes, reported to occur in other crustaceans (Reinhard 1956; Feldmann 1988; Zelmer \& Esch 1998; Hall et al. 2007; Lafferty \& Kuris 2009).

Whatever the ultimate explanation of the modification of the ventral border, if further studies can confirm the correlation with salinity, this feature could be another ecophenotypical character linked to salinity variations, such as the well-known adaptation to develop nodes as a reaction to difficult osmoregulation processes (Frenzel et al. (2012) with references therein).

\section{Acknowledgements and Funding}

The authors are very grateful to the Italian Ostracodologists' Group who enabled sampling of the Trapani-Paceco salt pans during the annual meeting in 2015. Many thanks to Sergio Lo Mastro for the SEM pictures.

\section{Scientific editing by Alan Lord}

\section{References}

Aladin, N.V. 1993. Salinity tolerance, morphology and physiology of the osmoregulation organs in Ostracoda with special reference to Ostracoda from the Aral Sea. In:Jones, P. \& McKenzie K. (eds) Ostracoda in Earth and Life Sciences. A.A. Balkema, Rotterdam, 387-404.

Baneschi, I. 2007. Geochemical and environmental study of a coastal ecosystem: Massaciuccoli lake (Northern Tuscany, Italy). Phd thesis, Geochemistry, Università degli studi Ca' Foscari di Venezia, https://tel.archives-ouvertes.fr/ tel-00400140

Boomer, I. \& Frenzel, P. 2011. Possible environmental and biological controls on carapace size in Cyprideis torosa (Jones, 1850). Joannea Geologie und Paläontologie, 11, 26-27.

Boomer, I., Frenzel, P. \& Feike, M. 2016. Salinity-driven size variability in Cyprideis torosa (Ostracoda, Crustacea). Journal of Micropalaeontology. First published online July 4, 2016, http://doi.org/10.1144/jmpaleo2015-043

Carbonel, P. 1982. Les Ostracodes, traceurs des variations hydrologiques dans des systèmes de transition eaux douces-eaux salées. Mémoirs de la Societé géologique de France, 8, 117-128.

Clarke, K.R. \& Gorley, R.N. 2006. Primer ver. 6: computer program. Primer-E Ltd, Plymouth.

Feldmann, R.M. 1988. Parasitic castration of the crab, Tumidocarcinus giganteus Glaessner, from the Miocene of New Zealand: Coevolution within the Crustacea. Journal of Paleontology, 72, 493-498.

Frenzel, P., Schulze, I., Pint, A., Boomer, I. \& Feike, M. 2011. Salinity dependant morphological variation in Cyprideis torosa. Joannea Geologie und Paläontologie, 11, 59-61.

Frenzel, P., Schulze, I. \& Pint, A. 2012. Noding of Cyprideis torosa valves (Ostracoda) - a proxy for salinity? New data from field observations and a long-term microcosm experiment. International Review of Hydrobiology, 97, 314-329.

Gliozzi, E., Rodriguez-Lazaro, J. \& Pipík, R. 2016. The Neogene Mediterranean origin of Cyprideis torosa (Jones, 1850). Journal of Micropalaeontology. First published online December 22, 2016, http://doi.org/10.1144/jmpaleo 2016-029.

Griffiths, H.I. \& Holmes, J.A. 2000. Non-marine ostracods \& Quaternary palaeoenvironments. Quaternary Research Association, Technical Guide, $\mathbf{8}$, $1-179$.

Grossi, F., Gliozzi, E., Anadón, P., Castorina, F. \& Voltaggio, M. 2015. Is Cyprideis agrigentina Decima a good palaeosalinometer for the Messinian Salinity Crisis? Morphometrical and geochemical analyses from the

Table 2. Salinity and percentage occurrence of the straight and sigmoidal ventral border specimens of Cyprideis torosa in the studied localities

\begin{tabular}{|c|c|c|c|c|c|c|c|}
\hline Localities & Salinity (\%o) & $\%$ Sigmoidal M & $\%$ Straight M & $\%$ Sigmoidal F & $\%$ Straight F & $\%$ Sigmoidal F $+M$ & $\%$ Straight $\mathrm{F}+\mathrm{M}$ \\
\hline Massaciuccoli & $0.6-0.77$ & 0 & 100 & 0 & 100 & 0 & 100 \\
\hline Trasimeno & $0.84-0.89$ & 0 & 100 & 0 & 100 & 0 & 100 \\
\hline Galia & 61 & 14.29 & 85.71 & 0 & 100 & 6.67 & 93.33 \\
\hline Salinella & 70 & 21.05 & 78.95 & 15.79 & 84.21 & 18.42 & 81.58 \\
\hline Bella & 80 & 75 & 25 & 11.11 & 88.89 & 30.77 & 69.23 \\
\hline Hyperhaline & $44-80$ & 27.5 & 72.5 & 7.8 & 92.2 & 17.6 & 82.4 \\
\hline
\end{tabular}

M, male; F, female. 
Eraclea Minoa section (Sicily). Palaeogeography, Palaeoclimatology, Palaeoecology, 419, 75-89.

Hall, S.R., Becker, C. \& Càceres, C.A. 2007. Parasitic castration: a perspective from a model of dynamic energy budgets. Integrative and Comparative Biology, 47, 295-309.

Keyser, D. 2005. Histological peculiarities of the noding process in Cyprideis torosa (Jones) (Crustacea, Ostracoda). Hydrobiologia, 538, 95-106.

Keyser, D. \& Aladin, N. 2004. Noding in Cyprideis torosa and its causes. Studia Quaternaria, 2, 19-24.

Krstić, N. 1968. Ostracodes des couches Congeriennes 1: Cyprideis I. Bulletin du Museum d'Histoire Naturelle de Belgrade, Serie A, 23, 107-151.

Lafferty, K.D. \& Kuris, A.M. 2009. Parasitic castration: the evolution and ecology of body snatchers. Trends in Parasitology, 25, 564-572.

Ligios, S. \& Gliozzi, E. 2012. The genus Cyprideis Jones, 1857 (Crustacea, Ostracoda) in the Neogene of Italy: A geometric morphometric approach Revue de micropaléontologie, 55, 171-207.

Ligios, S., Benvenuti, M., Gliozzi, E., Papini, M. \& Rook, L. 2008. Late Miocene palaeoenvironmental evolution of the Baccinello-Cinigiano Basin (Tuscany, central Italy) and new autoecological data on rare fossil fresh- to brackish-water ostracods Palaeogeography, Palaeoclimatology, Palaeoecology, 264, 277-287.

Linhart, J., Brauneis, W., Neubauer, W. \& Danielopol, D.L. 2006 Morphomatica, Computer Program Version 1.6, Graz, http://palstrat. uni-graz.at/morphomatica/morphomatica_e.htm

Maccotta, A., De Pasquale, C., Caruso, A., Cosentino, C., Alonzo, G. \& Conte, P. 2013. Reconstruction of the environmental evolution of a Sicilian saltmarsh (Italy). Environmental Science and Pollution Research, 20, 4847-4858, http:// doi.org/10.1007/s11356-012-1445-4

Mezger, E. 2012. How dry was the Messinian Salinity Crisis? A molecular biogeochemical study of the Eraclea Minoa (Sicily) section, Italy, http:/ dspace.library.uu.nl/handle/1874/273637

Neale, J.W. 1988. Ostracods and paleosalinity reconstruction. In: De Deckker, P., Colin, J-P. \& Peypouquet, J-P. (eds) Ostracoda in the Earth Sciences. Elsevier, Amsterdam, 125-155.

Pint, A., Frenzel, P., Fuhrmann, R., Scharf, B. \& Wennrich, V. 2012. Distribution of Cyprideis torosa (Ostracoda) in Quaternary athalassic sediments in Germany and its application for palaeoecological reconstructions. International Review of Hydrobiology, 97, 330-335.
Reinhard, E.G. 1956. Parasitic castration of Crustacea. Experimental Parasitology, 5, 79-107.

Rodriguez-Lazaro, J. \& Ruiz-Muñoz, F. 2012. A general introduction to Ostracods: morphology, distribution, fossil record and applications. In Horne, D.J., Holmes, J.A., Rodriguez-Lazaro, J. \& Viehberg, F.A. (eds) Ostracoda as Proxies for Quaternary Climate Change. Developments in Quaternary Science, 17. Elsevier, Amsterdam, 1-14.

Rohlf, F.J. 2009. TpsDig, digitize landmarks and outlines, version 2.14. Department of Ecology and Evolution, State University of New York a Stony Brook, New York. http://life.bio.sunysb.edu/morph/

Rosenfeld, A. \& Vesper, B. 1977. The variability of the sieve-pores in recent and fossil species of Cyprideis torosa (Jones, 1850) as an indicator for salinity and paleosalinity. In: Löffler, H. \& Danielopol, D. (eds) Aspects of ecology and zoogeography of Recent and fossil Ostracoda. Junk Publishers, The Hague, $55-67$.

Ruggieri, G. 1962. Gli ostracodi marini del Tortoniano (Miocene medio superiore) di Enna, nella Sicilia centrale. Palaeontographia Italica, LVI, 1-68.

Sandberg, P. 1964. The ostracod genus Cyprideis in the Americas. Stockholm Contributions in Geology, 12, 1-178.

Schäfer, H.W. 1953. Über Meeres- und Brackwasserostracoden aus dem Deutschen Küstengebiet mit 2. Mitteilung über die Ostracodenfauna Griechenlands. Hydrobiologia, 5, 351-389.

Van Harten, D. 1996. Cyprideis torosa (Ostracoda) revisited. Of salinity, nodes and shell size. In: Keen, M.C. (ed.) Proceedings of the second European Ostracodologists Meeting. British Micropalaeontological Society, London, 191-194.

Van Harten, D. 2000. Variable noding in Cyprideis torosa (Ostracoda, Crustacea): an overview, experimental results and a model from Catastrophe Theory. Hydrobiologia, 419, 131-139.

Vesper, B. 1975. To the problem of noding on Cyprideis torosa (Jones, 1850). In: Swain, F.M. (ed.) Biology and Paleobiology of Ostracoda, A Symposium. University of Delaware. Bulletins of American Paleontology, 65, 205-216.

Zelmer, D.A. \& Esch, G.W. 1998. Interactions between Halipegus occidualis and its ostracod second intermediate host: evidence for castration? Journal of Parasitology, 84, 778-782. 